\title{
REMISIÓN BIOQUÍMICA DE PACIENTES ACROMEGÁlICOS SOMETIDOS A CIRUGÍA ENDOSCÓPICA
}

\author{
Hernández Durán, Silvia ${ }^{1,2,3}$; Obando Valverde, Andrés ${ }^{3,4}$ y Esquivel Miranda, Miguel Ángel ${ }^{1,2,3}$ \\ ${ }^{1}$ School of Medicine, University of Costa Rica, San Pedro de Montes de Oca, San José. \\ ${ }^{2}$ Neurological Surgery Department, Hospital México, San José, Costa Rica. \\ 3Programa de Investigación en Neurocirugía y Órganos de los Sentidos - PINECOS (Research Program in Neurosurgery \\ and Sensory Organs), School of Medicine, University of Costa Rica, San José. \\ ${ }^{4}$ Otolaryngology Department, Hospital México, San José, Costa Rica.
}

\begin{abstract}
Resumen: Objetivo. La cirugía transnasal transesfenoidal endoscópica es la base del tratamiento para la acromegalia en nuestro centro. Realizamos un estudio retrospectivo de 2008 - 2011 para determinar si este abordaje induce remisión bioquímica, y comparamos nuestras observaciones con series publicadas.

Métodos. Analizamos retrospectivamente nuestra base de datos, e identificamos los pacientes sometidos a cirugía transnasal transesfenoidal endoscópica como tratamiento primario de acromegalia. Valoramos las imágenes y perfiles endocrinológicos pre-operatorios, y utilizamos los criterios del Consenso de Acromegalia de 2009 para determinar la remisión bioquímica.

Resultados. Ocho pacientes recibieron adenomectomía endoscópica primaria. Uno tenía un microadenoma, otro un macroadenoma no invasivo, y seis presentaban macroadenomas invasivos. La media de los niveles del factor de crecimiento similar a la insulina tipo I tres meses post-cirugía fueron $633 \mathrm{ng} / \mathrm{mL}(199 \mathrm{ng} / \mathrm{mL}$ $1600 \mathrm{ng} / \mathrm{mL})$, mientras que los de la hormona de crecimiento fueron 10,20 ng/mL (0,96 ng/mL - 16,60 $\mathrm{ng} / \mathrm{mL}$ ). Dos pacientes cumplieron criterios de remisión; un macroadenoma no invasivo y un microadenoma. Cuatro de los pacientes restantes tuvieron remisión con análogos de somatostatina.

Conclusiones. Este es el primer reporte de cirugía transnasal transesfenoidal endoscópica como terapia primaria de acromegalia en Costa Rica. La cura en pacientes con macroadenomas grandes e invasivos puede ser difícil y requiere de terapia multimodal.
\end{abstract}

Revista electrónica publicada por el Departamento de Farmacología de la Escuela de Medicina de la Universidad de Costa Rica, 2060 San José, Costa Rica. ${ }^{\circledR}$ All rights reserved. Licensed under a Creative Commons Unported License. 
Palabras clave: Acromegalia, Procedimiento quirúrgico endoscópico, Adenoma pituitario, Somatostatina

\title{
BIOCHEMICAL REMISSION OF ACROMEGALIC PATIENTS WHO UNDERWENT ENDOSCOPIC SURGERY
}

\begin{abstract}
Objective. Endoscopic transnasal transsphenoidal surgery is the cornerstone of therapy for acromegaly at our Center. We conducted a retrospective study to determine whether this approach induced biochemical remission, and compared our observations to published series.

Methods. We performed a retrospective analysis of our Pituitary Surgery database, and identified all patients that underwent endoscopic transnasal transsphenoidal surgery as primary treatment for acromegaly. Preoperatory imaging and endocrinological panels were assessed, and the 2009 Acromegaly Consensus Group criteria were used to determine whether biochemical remission was achieved.

Results. Eight patients underwent primary endoscopic adenomectomy. One had a microadenoma, one had a non-invasive macroadenoma, and the remaining six patients presented invasive macroadenomas. Median insulin-like growth factor I levels at three months of surgery were $633 \mathrm{ng} / \mathrm{mL}(199 \mathrm{ng} / \mathrm{mL}-1600 \mathrm{ng} / \mathrm{mL})$, while growth hormone levels were $10,20 \mathrm{ng} / \mathrm{mL}(0,96 \mathrm{ng} / \mathrm{mL}-16,60 \mathrm{ng} / \mathrm{mL})$. Two patients met criteria for remission, with a non-invasive macroadenoma and a microadenoma. Four of the remaining patients achieved remission after administration of somatostatin analogues.

Conclusions. This is the first report of endoscopic transnasal transsphenoidal surgery as primary treatment for acromegaly in Costa Rica. Attaining cure in patients with large, invasive macroadenomas can be elusive, and a multi-modal approach is necessary.
\end{abstract}

Key words: Acromegaly; Endoscopic surgical procedure; Pituitary adenoma; Somatostatin

\section{INTRODUCCIÓN}

Hormone-secreting pituitary adenomas are responsible for approximately $99 \%$ of the cases of acromegaly. Therefore, over the past forty years, the treatment of choice for this condition has been transsphenoidal surgery (TSS) for tumor resection. The effectiveness of TSS has been shown by numerous authors, but the remission rates appear to significantly drop for invasive adenomas [1]. In Latin America, and at our institution, Hospital Mexico, many patients with acromegaly present large tumors that are not confined to the sella turcica [2]. However, access to somatostatin analogues is not always subsidized by government agencies, which renders the management of large, invasive lesions challenging from both medical and socioeconomic standpoints. Because surgical 
treatment is the cornerstone of therapy for acromegaly at our center regardless of tumor size and extrasellar expansion, we conducted a retrospective study of the Pituitary Surgery Database of the recently founded Skull Base Surgery Unit of our Center. Our interest was to present the initial results of endoscopic transnasal transsphenoidal surgery (ETSS) at our Unit, and compare them, in terms biochemical remission in patients with growth hormone (GH)-secreting adenomas, to other published series.

\section{PATIENTS AND METHODS}

We performed a retrospective analysis of our Pituitary Surgery database, where we identified eleven patients with GH-secreting adenomas. These patients had been referred to our Center for neuroendocrinological management, and they underwent ETSS for tumor resection between January 2008 and September 2011. The evaluation was performed with the authorization of the Ethics Committee of our Center, (CLOBI protocol number: CLOBI-HM-027-2011) and informed consent was obtained from all subjects regarding the proposed operation.

The inclusion criteria were the following: diagnosis of acromegaly based on GH levels $>1$ $\mathrm{ng} / \mathrm{mL}$, insulin-like growth factor (IGF) I levels greater than the normal range for age and sex, and imaging evidence for a pituitary adenoma. Patients must have undergone ETSS at our Center between January 2008 and September 2011 as their primary treatment, and they must have been followed for at least six months by our multidisciplinary team of endocrinologists, neurosurgeons, and ear, nose and throat (ENT) surgeons with laboratory analyses and imaging.

Preoperative endocrinological assessment was performed at our Center by means of radioimmunoassay. A full endocrinological panel was obtained, in order to determine serum GH and IGF-I levels, as well as further hormone deficiencies. If other hormone disorders were identified, the corresponding treatment was started. In the post-operative period, serum GH and IGF-I were assessed at three and six months. The 2009 Acromegaly Consensus Group criteria [3] for cure were used to determine biochemical remission in all of our patients. Accordingly, patients with normal IGF-I levels for age and sex, and random GH levels lower than 1,0 ng/mL, three months after surgery, were considered in biochemical remission. Alternatively, patients with elevated IGF-I levels at three months, were considered in biochemical remission only if their GH nadir during an oral glucose tolerance test (OGTT), was less than $0,4 \mathrm{ng} / \mathrm{mL}$.

In case that biochemical remission was not achieved, the individual cases were raised to the Board of Directors of the Pharmacotherapy Committee of our institution. Each case was analyzed by this Committee in order to determine whether the patient would warrant a somatostatin analogue agent. If the decision was positive, somatostatin analogues were administered and IGF-I and GH levels were measured six months later to assess biochemical remission based on the aforementioned criteria.

All patients were evaluated by an ophthalmologist for visual acuity and visual fields. The latter were assessed through static perimetry. Visual field compromise, such as homonymous hemianopia, bitemporal hemianopia or quadrantanopia, was then correlated to imaging findings.

All patients were also classified according to their comorbidities. Hypertension, dyslipidemia, diabetes mellitus, obstructive sleep apnea, osteoarthritis and cardiovascular disease were sought in these patients in order to assess acromegaly manifestations.

All patients underwent pre-operatory radiological evaluation by means of contrastenhanced computed tomography (CECT) or gadolinium-enhanced magnetic resonance imaging (MRI).All pituitary adenomas were classified according to maximum tumor diameter as microadenomas $(<10 \mathrm{~mm})$ or macroadenomas $(>$ 
$10 \mathrm{~mm}$ ). They were further classified according to the modified Hardy system considering their extension and invasion. Imaging studies were obtained post-operatively to assess tumor persistence or recurrence. Because of the resources of our institution, it is possible to perform both pre-operative CECT and MRI, but the post-operative follow-up imaging is mainly performed by means of CECT. Only select cases undergo post-operative MRI because of the availability of these studies in our socioeconomic context.

All patients underwent endoscopic transnasal transsphenoidal surgery at our Center. An ENT surgeon was responsible for the nasal and sphenoidal phases of the operation, during which the middle turbinate was identified and resected in order to create an adequate surgical pathway. Ethmoidectomies were not routinely performed. An ample sphenoidotomy was completed in all cases, and all the anatomic landmarks inside the sphenoid sinus were explored before proceeding with the adenomectomy.

The sellar phase of the surgery was then performed by a neurosurgeon, who was responsible for the tumor removal. Once the neoplasm was resected, the endoscope was moved forward into the cavity, in order to identify tumor remnants in the recesses created by the descent of the suprasellar cistern. Sellar repair was performed in cases of extended approaches or intraoperative cerebrospinal fluid (CSF) leakage by means of dural substitutes, surgicel $\AA$, gelfoam $\AA$ or fibrin glue. Nasal packing was not routinely performed after the surgery.

Patients were then monitored closely for post-operative complications, such as meningitis, epistaxis, pneumocephalus, CSF leakage, pneumonia and death. Strict measurement of urine output and urinary density were also carried out in order to identify diabetes insipidus.

\section{RESULTS}

We identified eleven patients who underwent ETSS for GH-secreting adenomas between January 2008 and September 2011. From this initial group, two patients had already undergone craniotomies before resecting the $\mathrm{GH}$ secreting pituitary adenoma, and were therefore excluded. Another patient was excluded because she had received pre-surgical medical treatment with somatostatin analogues. The remaining eight patients were composed by seven males and one female, with a median age of 41,5 years (min:31, max: 57).

Among our cohort, pre-operatory median IGF-I levels were 615,5 ng/mL (min: $555 \mathrm{ng} / \mathrm{mL}$, max: $1281 \mathrm{ng} / \mathrm{mL}$ ), while the median values for $\mathrm{GH}$ were $20,70 \mathrm{ng} / \mathrm{mL}$ (min: 3,13, max: > 40,00). No thyroid hormone or testosterone deficiencies were identified. One patient suffered from hypocortisolism, which was treated with hydrocortisone, $25 \mathrm{mg}$ per day. Hyperprolactinemia was evinced in two of our patients.

Only one patient exhibited visual field disturbances, which consisted of superior bitemporal hemianopia. On imaging, this patient was found to have a tumor with suprasellar extension. Further comorbidities included hypertension (4/8), dyslipidemia (2/8), diabetes mellitus (2/8), and cardiovascular disease $(1 / 8)$. No cases of obstructive sleep apnea or osteoarthritis were identified.

The eight patients underwent radiologic assessment of their lesion with CECT scan, and six had gadolinium-enhanced MRI in addition. Seven patients presented macroadenomas, while only one patient had a microadenoma of $4 \times 5 \mathrm{~mm}$.

From the seven macroadenomas, five cases exhibited extrasellar extension or invasion. The majority of the cases (5/7) exhibited local spread into the sphenoid sinus with focal perforation of the sellar floor, and $3 / 7$ evidenced extension into the cavernous sinus (Table 1 ). 
The median duration of the surgical procedure was 217.50 minutes (min: 150 minutes, max: 335 minutes), and the median hospital stay for all patients was 7days (min:5, max: 11). Even though the surgical procedures were not followed by significant complications, median hospital stay of 7 days was due to endocrine control- Several patients live in remote areas where access to endocrine follow-up is limited, so it was in our best interest to discharge these patients with optimal endocrine control.
Among the cohort, the median IGF-I levels at three months after surgery were $633 \mathrm{ng} / \mathrm{mL}$ (min: $199 \mathrm{ng} / \mathrm{mL}$, max: $1600 \mathrm{ng} / \mathrm{mL}$ ), while the corresponding GH levels were $10,20 \mathrm{ng} / \mathrm{mL}$ (min:0,96 ng/mL, max: 16,60 ng/mL). At six months post-operatory, the patients presented median IGF-I levels of $626 \mathrm{ng} / \mathrm{mL}$ (min: $98 \mathrm{ng} / \mathrm{mL}$, max: $1497 \mathrm{ng} / \mathrm{mL}$ ), and GH levels of $8,21 \mathrm{ng} / \mathrm{mL}$ (min: 0,24 ng/mL, max: 17,50 ng/mL). From these patients, one did not have IGF-I and GH values, three months after surgery; nevertheless, at six months, this patient met criteria for biochemical remission (Table 2).

Table 1. Modified Hardy classification for the extension of the GH-secreting adenomas treated at Hospital Mexico, San Jose, Costa Rica by means of primary ETSS between years 2008 - 2011

\begin{tabular}{|c|c|c|}
\hline Suprasellar/Parasellar extension & No of cases & Percentage (\%) \\
\hline 0: None & 5 & 62,5 \\
\hline A: expansion intro suprasellar cistern & 0 & 0 \\
\hline B: anterior recesses of 3 rd ventricle obliterated & $\mathbf{0}$ & $\mathbf{0}$ \\
\hline C: floor of 3rd ventricle grossly displaced & 0 & $\mathbf{0}$ \\
\hline D: intracranial (intradural); anterior, middle or posterior fossa & 0 & 0 \\
\hline E: Into or beneath the cavernous sinus (extradural) & 3 & 37,5 \\
\hline \multicolumn{3}{|l|}{ Invasion/Spread } \\
\hline I: sella normal or focally expanded, tumor $\leq 10 \mathrm{~mm}$ & 1 & 12,5 \\
\hline II: sella enlarged; tumor $\geq 10 \mathrm{~mm}$ & 2 & 25 \\
\hline III: Localized perforation of the sellar floor & 5 & 62,5 \\
\hline IV: diffuse destruction of sellar floor & 0 & 0 \\
\hline V: spread via CSF or blood-borne & $\mathbf{0}$ & 0 \\
\hline TOTAL & 8 & 100 \\
\hline
\end{tabular}

Another patient also achieved biochemical remission based on his endocrinological panels at three and six months post-surgery. These patients had a non-invasive macroadenoma and a microadenoma, respectively.

From the six patients who did not achieve biochemical remission, five underwent additional CECT imaging assessment within one year after surgery, in addition to the immediate postoperative scans. None of the patients showed persistence and/or recurrence of the adenoma in the imaging studies (Figure 1).

Five cases were raised to and approved by the Pharmacotherapy Committee of our Institution, and received somatostatin analogues (Sandostatin LAR $®$ - Octreotide) 8 months after the surgery (min: 4 months, max: 18 months). The median random $\mathrm{GH}$ levels of these patients after receiving medical therapy were $0,82 \mathrm{ng} / \mathrm{mL}$ (min: 0,34 max: $4,46 \mathrm{ng} / \mathrm{mL}$ ) and the IGF-I ones were $370 \mathrm{ng} / \mathrm{mL}$ 
(min: $246 \mathrm{ng} / \mathrm{mL}$, max: $617 \mathrm{ng} / \mathrm{mL}$ ). Four of these patients achieved biochemical remission after the addition of the drug, whereas one remained with elevated GH and IGF-levels.

Table 2. Initial, 3-month and 6-month post-operative GH and IGF-I levels of patients undergoing primary ETSS to treat their acromegaly between years 2008 - 2010 at Hospital Mexico, San Jose, Costa Rica.

\begin{tabular}{|c|c|c|c|c|c|c|c|}
\hline Patient & $\begin{array}{c}\text { Type of adenoma } \\
\text { (modified Hardy scale) }\end{array}$ & $\begin{array}{c}\text { Initial GH } \\
\text { (ng/mL) }\end{array}$ & $\begin{array}{c}\text { 3-mo post- } \\
\text { op GH } \\
\text { (ng/mL) }\end{array}$ & $\begin{array}{l}\text { 6-mo post- } \\
\text { op GH } \\
\text { (ng/mL) }\end{array}$ & $\begin{array}{c}\text { Initial IGF-I } \\
\text { (ng/mL) }\end{array}$ & $\begin{array}{l}\text { 3-mo post-op } \\
\text { IGF-I (ng/mL) }\end{array}$ & $\begin{array}{l}\text { 6-mo post-op } \\
\text { IGF-I (ng/mL) }\end{array}$ \\
\hline 1 & 0 II & 24,50 & 16,60 & 15,60 & 1066 & 633 & 645 \\
\hline 2 & 0 III & $>40,00$ & 3,65 & 3,00 & 1111 & 663 & 681 \\
\hline 3 & E III & 8,01 & 15,40 & 17,50 & 570 & 589 & 571 \\
\hline 4 & E III & $>40,00$ & 5,85 & 3,77 & 624 & 593 & 607 \\
\hline 5 & 0 III & 14,80 & 10,20 & 12,65 & 570 & 908 & 832 \\
\hline 6 & E III & $>40,00$ & 13,60 & 13,10 & 1281 & 1600 & 1497 \\
\hline 7 & Microadenoma & 3,13 & ,96 & 0,24 & 607 & 199 & 164 \\
\hline 8 & 00 & 16,90 & N/A & .53 & 555 & N/A & 98 \\
\hline
\end{tabular}

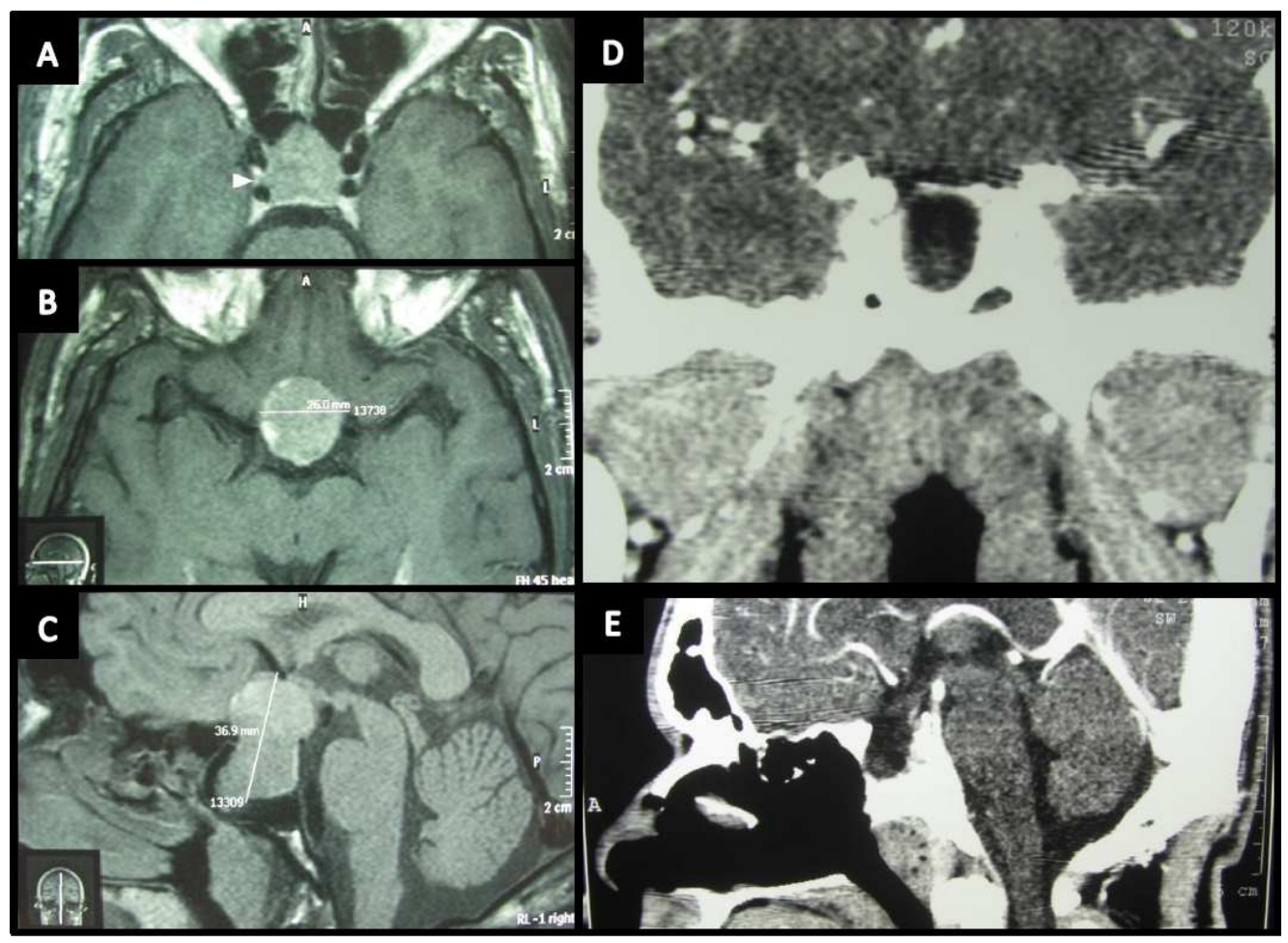

Figure 1: A - C) PreoperatoryT1-weighted axial and sagittal cuts showing cavernous sinus invasion and sphenoid sinus erosion of the macroadenoma. D - E) Post-operative CECT, axial and sagittal cuts, showing no tumor remaining.

Revista electrónica publicada por el Departamento de Farmacología de la Escuela de Medicina de la Universidad de Costa Rica, 2060 San José, Costa Rica. ${ }^{\circledR}$ All rights reserved. Licensed under a Creative Commons Unported License. 


\section{DISCUSSION}

Because acromegaly is associated with three-fold higher morbidity and mortality than the average person, the goal of its treatment is to achieve normal GH and IGF-I levels. ETSS has become the surgical treatment of choice at our institution because it offers improved visualization, preservation of sinonasal function, improvement in the resection of suprasellar and parasellar components of the adenoma, and reduction of hospital length of stay when compared to microscopic transsphenoidal and transcranial techniques [4-6]. Furthermore, the improved visualization and identification of extrasellar components through the advancement of the endoscope into the tumor cavity leads to a greater extent of resection and safety [7]. In our cohort, gross total resection was achieved in all cases, and no evidence of residual tumor in postsurgical imaging studies was found, which supports this notion.

On the other hand, the complications of ETSS are usually minor and include transient diabetes insipidus and CSF leak, with incidences comparable or inferior to those reported with the microsurgical technique [8-9]. Our data confirm the low morbidity and mortality of this surgical procedure, with only three cases of transient diabetes insipidus, and no other reported complications.

In spite of good surgical outcomes, disease control in acromegaly can be elusive. Several literature reports estimate that approximately 40 $60 \%$ of macroadenomas, particularly those with extrasellar invasion, are not controlled by surgery alone [10]. One of the first studies performed in the United States for ETSS in GH-secreting adenomas reported $42 \%$ of post-surgical endocrinological remission in macroadenomas [11]. In this cohort, $41.7 \%$ of patients exhibited invasion of the cavernous sinus, and $29.2 \%$ had suprasellar tumor extension. These findings were reproduced by Gondim et al [12] in their retrospective analysis of 67 Brazilian patients, where they found that less than $45 \%$ of patients with sphenoid sinus invasion had biochemical control of their acromegaly after primary ETSS. Additionally, van Bunderen et al [13] reported only $30 \%$ of remission after primary ETSS in their cohort of 30 Dutch patients, the majority of which exhibited extrasellar extension of their macroadenoma. Furthermore, in their retrospective study of 60 American patients, Jane et al [14] found that more invasive adenomas were significantly less likely to achieve biochemical remission after ETSS than those limited to the sella turcica, while Campbell et al [4] found that higher Hardy and Knosp grades were associated with significantly lower remission rates.

The data obtained from our cohort coincide with these international observations. The majority of our patients with macroadenomas (5/7) presented tumors with extrasellar extension and sphenoid sinus erosion, which has been demonstrated by numerous authors [4, 12-16] to significantly reduce the likelihood of biochemical remission after surgery. It is therefore not at all surprising that, in our cohort, those patients with smaller lesions (microadenoma and non-invasive macroadenoma) attained biochemical remission after primary surgical treatment, whereas those patients with invasive tumors failed to reach cure. Because of the size of our cohort and the recent foundation of the Endoscopic Skull Base Surgery Unit at our Center in 2008, our remission rates in invasive adenomas were to be expected.

The proximity of vital vascular and brain structures is what typically makes these lesions more surgically challenging, but remission can also be elusive due todural tumor microfoci that persistently hypersecrete GH and are not readily visualized and resected during surgery [17-18]. These microfoci were likely the reason for persistently elevated GH levels seen in our patients in spite of gross total resection as seen in the postoperative imaging studies.

Because of the latter, the Acromegaly Consensus Group recommends multimodal treatment and involvement of a multidisciplinary 
team to treat invasive macroadenomas [19]. One of the alternatives in the management of these patients is the use of pre-operative somatostatin analogues. Because these drugs can lead to normalized GH and IGF-I levels, as well as tumor shrinkage, it is thought that they could improve the likelihood of biochemical remission after a radical resection [20]. Several studies have confirmed these theoretical advantages [22-25], but they differ from one another in patient selection, class of somatostatin analogue used, duration of treatment, variables analyzed, and follow-up. Therefore, there are no international, validated guidelines for the use of pre-surgical somatostatin analogues. Nevertheless, the Latin American panel of experts advocates for the use of first-line medical therapy as a viable alternative to surgery, particularly in patients with invasive adenomas [2]. The main argument to support this recommendation is the prospective, multicenter study performed by Mercado et al [26] to assess the efficacy of primary octreotide in a Latin American population, which provides more epidemiologically-relevant data for our region, according to their observations.

The cost of medical treatment, however, is a major limiting factor in developing countries such as ours. Therefore, at our institution we primarily perform surgical excision by means of ETSS, and then assess the need for medical therapy in case of persistence or recurrence. This approach corresponds to the more traditional algorithms published $[10,17,18]$, and is acceptable because of the low morbidity and mortality associated to the surgical procedure at our Center. Nevertheless, it is important to point out that the majority of our patients present large, invasive tumors, and that surgery is not likely to provide endocrine remission by itself.

\section{CONCLUSIONS}

Optimization of the acromegaly treatment protocols at our Institution is necessary. The inclusion of somatostatin analogues in the postoperative period as part of the routine management of patients with invasive $\mathrm{GH}$ secreting macroadenomas, should be pursued, so that our patients do not suffer from the deleterious effects of raised IGF-I and GH levels.

\section{REFERENCES}

1. Nomikos P, Buchfelder M, Fahlbusch R. The outcome of surgery in 668 patients with acromegaly using current criteria of biochemical 'cure'. Eur J Endocrinol. 2005; 152: 379-87.

2. Barkan A, Bronstein M, Bruno O, Cob A, Espinosa-de-losMonteros A, Gadelha M, et al. Management of acromegaly in Latin America: expert panel recommendations. Pituitary. 2010; 13:168-175.

3. Giusina A, Chanson P, Bronstein MD, Klibanski A, Lamberts S, CasanuevaFF, et al. A consensus on criteria for cure of acromegaly. J Clin Endocrinol Metab. 2010; 95(7):3141-8.

4. Campbell P, Kenning E, Andres D, Yadla S, Rosen M, Evans J. Outcomes after a purely endoscopic transsphenoidal resection of growth hormone-secreting pituitary adenomas. Neurosurg Focus 2010; 29(4):E5.

5. dos Santos ARL, Neto RMF, Veiga JCE, Viana J, Scaliassi NM, Lancellotti CLP, et al. Endoscopic endonasal transsphenoidal approach for pituitary adenomas. Arq Neuropsiquiatr. 2010; 68(4):608-12.

6. Gondim JA, Schops M, de Almeida JP, de Albuquerque LA, Gomes E, Ferraz T, et al. Endoscopic endonasal transsphenoidal surgery: surgical results of 228 pituitary adenomas treated in a pituitary center. Pituitary. 2010; 13(1):68-77.

7. Tabaee A, AnandVK, Barrón Y, Hiltzik DH, Brown SM, Kacker A, et al. Endoscopic pituitary surgery: a systematic review and meta-analysis. J Neurosurg. 2009; 111(3):545-54.

8. Dehdashti A, Ganna A, Karabatsou K, Gentili F. Pure endoscopic endonasal approach for pituitary adenomas: early surgical results in 200 patients and comparison with previous microsurgical series. Neurosurgery. 2008; 62(5):1006-1015.

9. O'Malley BW, Grady MS, Gabel BC, Cohen MA, Heuer GG, Pisapia J, et al. Comparison of endoscopic and microscopic removal of pituitary adenomas: single- 
surgeon experience and the learning curve. Neurosurg Focus. 2008; 25(6): E10.

10. Melmed S, Colao A, Barkan A, Molitch M, Grossman AB, Kleinberg D, et al. Guidelines for Acromegaly Management: An Update. J Clin Endocrinol Metab. 2009; 94(5):1509-1517.

11. Hofstetter CP, Mannaa RH, Mubita L, AnandVK, Kennedy JW, Dehdashti AR, et al. Endoscopic endonasal transsphenoidal surgery for growth hormone-secreting pituitary adenomas. Neurosurg Focus. 2010; 29(4):E6.

12. Gondim JA, Almeida JP, de Albuquerque LA, Gomes E, Schops M, Ferraz T. Pure endoscopic transsphenoidal surgery for treatment of acromegaly: results of 67 cases treated in a pituitary center. Neurosurg Focus. 2010; 29(4):E7.

13. van Bunderen $C$, van Varsseveld N, Baayen J, van Furth W, Sanchez Aliaga E, HazewinkelMJ, et al. Predictors of endoscopic transsphenoidal surgery outcome in acromegaly: patient and tumor characteristics evaluated by magnetic resonance imaging. Pituitary. 2013; 16(2):158-67.

14. Jane Jr. JA, Starke RM, Elzoghby MA, Reames DL, Payne SC, Thorner MO, et al. Endoscopic transsphenoidal surgery for acromegaly: remission using modern criteria, complications, and predictors of outcome. J Clin Endocrinol Metab. 2011; 96:2732-40.

15. Ikeda H, Sato S, Saginoya T, Kudo T, Watanabe K. The outcome of surgery in patients with growth hormone secreting adenomas: early surgical intervention is essential for improving the surgical cure rate. J Metabolic Synd. 2012; S2.

16. Roelfsema F, Biermasz N, Pereira A. Clinical factors involved in the recurrence of pituitary adenomas after surgical remission: a structured review and metaanalysis. Pituitary. 2012; 15:71-83.

17. Melmed S. Acromegaly pathogenesis and treatment. J Clin Invest. 2009; 119:3189-202.

18. Melmed S. Acromegaly. In: The Pituitary. Melmed S, ed. Academic Press, United States. Third edition2010, pp. 433-70.

19. Melmed S, CasanuevaFF, Klibanski A, Bronstein MD, Chanson P, Lamberts SW, et al. A consensus on the diagnosis and treatment of acromegaly complications. Pituitary. 2012; 16(3):294-302.

20. Carlsen SM, Lund-Johansen M, Schreiner T, Aanderud S, Johannesen O, Svartberg J, et al. Preoperative octreotide treatment in newly diagnosed acromegalic patients with

Revista electrónica publicada por el Departamento de Farmacología de la Escuela de Medicina de la Universidad de Costa Rica, 2060 San José, Costa Rica. ${ }^{\circledR}$ All rights reserved. Licensed under a Creative Commons Unported License. Contáctenos: rev.med.ucr@gmail.com. Tel: (506) 25-11 4492, Fax: 25-11-4489. macroadenomas increases cure short-term postperative rates: a prospective, randomized trial. J Clin Endocrinol Metab. 2008; 93(8):2984-90.

21. Bolanowski M, Bar-Andziak E, Kos-Kudla B, Krzyzanowska-Swiniarska B, Lewinski A, LommaBogdanov E, et al. Consensus statement of the Polish Society for Endocrinology: presurgical somatostatin analogs therapy in acromegaly. Neuro Endocrinol Lett. 2008; 29(1):59-62.

22. Mao ZG, Zhu YH, Tang HL, Wang DY, Zhou J, He DS, et al. Preoperative lanreotide treatment in acromegalic patients with macroadenomas increases short-term postoperative cure rates: a prospective, randomised trial. Eur J Endocrinol. 2010; 162(4):661-6.

23. Shen M, Shou X, Wang Y, Zhang Z, Wu J, Mao Y, et al. Effect of presurgical long-acting octreotide treatment in acromegaly patients with invasive pituitary macroadenomas: a prospective randomized study. Endocrine Journal. 2010; 57(12):1035-44.

24. Stevenaert A, Beckers A. Presurgical octreotide: treatment in acromegaly. Metabolism. 1996; 45(8 Suppl 1):72-4.

25. Yin J, Su CB, Xu ZQ, Yang Y, Ma Wb, Tao W, et al. Effect of preoperative use of long-acting octreotide on growth hormone secreting pituitary adenoma and transsphenoidal surgery. Chin Med Sci J. 2005; 20(1):236.

26. Mercado M, Borges F, Bouterfa H, Chang TC, Chervin A, Farrall AJ, et al. A prospective, multicentre study to investigate the efficacy, safety and tolerability of octreotide LAR(R) (long-acting repeatable octreotide) in the primary therapy of patients with acromegaly. Clin Endocrinol. 2007; 66:859-68.

\section{INFORMACION DE AUTOR:}

Hernández Durán, Silvia

Correo: drahernandezduran@gmail.com 


\title{
Publique en la Revista Médica de la Universidad de Costa Rica
}

\author{
Envíe sus trabajos a: rev.med.ucr@gmail.com
}

\section{Siga las normas de publicación y guías de autores para el formato del trabajo}

Proceso de publicación

\section{Generalidades}

El envió de un artículo a la Revista Médica de la Universidad de Costa Rica (de ahora en adelante citada como la Revista), no implica necesariamente la aceptación de este para su publicación.

La aceptación de un artículo para publicación, deberá cumplir con todas las normas de la Revista, ser de una calidad científica adecuada y aceptar incluir las mejoras propuestas por los revisores, si corresponde.

Los artículos se evaluarán siguiendo el orden de su ingreso. Los artículos deben ser enviados al email de la revista: rev.med.ucr@gmail.com

\section{Proceso de evaluación de los artículos}

Los artículos enviados a la revista están sujetos a una serie de pasos previos a su publicación. En primer lugar, el Consejo Editorial revisa los artículos que son enviados para verificar que cumplen con el formato de la revista y que todo está como se solicita en la guía de autores. Si algo falta el artículo se devuelve al autor para que complete el faltante. Cuando el artículo cumple a cabalidad con las normas de publicación que se presentan en la guía de autores, este es evaluado por el Comité Científico para verificar la calidad del contenido científico y la temática que aborda el mismo. En segundo lugar, una vez verificado todo y conociendo el área de la especialidad del trabajo se seleccionan dos revisores propuestos por el Comité Científico para evaluar el artículo. El trabajo de los revisores es gratuito y no se paga por dicha labor. Los revisores tendrán cerca de dos a tres semanas para expresar sus opiniones, si al cabo de ese tiempo no responden se buscará otros revisores para que realicen la labor. Cuando el proceso con los revisores está completo y, estos dieron su visto bueno para aceptar el artículo, es el Comité Científico el que los revisa de nuevo y emite un criterio para su publicación. En tercer lugar, finalmente el Consejo Editorial revisa los trabajos y los aprueba o rechaza según los criterios del Comité Científico y los revisores.

Los artículos que se quieran publicar en la Revista serán evaluados por al menos dos revisores especialistas en el tema. Los revisores pueden ser tanto especialistas nacionales, como extranjeros.

Los revisores serán nombrados por el Consejo Editorial y realizarán un análisis crítico y exhaustivo de los artículos. La evaluación será a doble ciego, es decir, los revisores no conocerán al autor del artículo y el autor tampoco sabrá quienes son los revisores.

Los artículos pueden ser rechazados, aceptados con condiciones o aceptados sin condicionantes.

Si el artículo es aceptado con condiciones, el autor deberá realizar las mejoras solicitadas por los revisores y la Revista en un plazo prudencial, o adjuntar cualquier material e información adicional que se le solicite para verificar la validez de las conclusiones y del estudio mismo. Si el autor no remite el material adicional solicitado o las correcciones, el artículo no será considerado para su publicación.

Para publicar un artículo deberá haber un dictamen positivo de los dos revisores. Si un dictamen es positivo y el otro negativo, se buscará un tercer revisor. Si el dictamen de este es negativo, el artículo no se publicará, pero si es positivo entonces se considerará su publicación. 
Será el Consejo Editorial el que finalmente aceptará o rechazará los artículos, apoyados en el dictamen del Comité Científico y los revisores, como se mencionó anteriormente.

Las decisiones del Consejo Editorial sobre la publicación de un artículo en particular son inapelables.

El contenido temático de los trabajos publicados en la Revista no serán modificados por esta y lo autores darán su visto bueno al artículo final antes de ser publicado.

Los artículos publicados en la revista podrán ser incluidos en diversos portales, repositorios, bases de datos, bibliotecas u otros sistemas de registro, que el Consejo Editorial estime conveniente, siempre y cuando estos sean gratuitos, de libre acceso y sin fines de lucro.

\section{Derechos de publicación}

Los editores y por ende la Universidad de Costa Rica se reservan los derechos de publicación.

Los artículos publicados serán de acceso gratuito y de libre difusión, solo para uso particular en docencia, investigación o actualización. No se autorizará ningún uso con fines comerciales o de lucro, por particulares o empresas.

Se permite la publicación de información (tablas, fotos, dibujos, gráficos o conclusiones) de los artículos de esta revista, siempre y cuando se especifique la fuente de su origen con una cita bibliográfica y aparezcan publicados en revistas, trabajos o libros de acceso gratuito. Cualquier otro uso requiere el consentimiento escrito del Editor de la Revista.

Los autores conservarán sus derechos sobre la propiedad intelectual de los trabajos publicados en esta Revista.

\section{Publicación gratuita}

La publicación de los artículos es totalmente gratuita, esta Revista no tiene fines de lucro. Ningún dinero, ni contribución será demandado en ningún paso del proceso editorial, desde la recepción del trabajo hasta su publicación.

\section{Responsabilidad del contenido de las publicaciones}

Las conclusiones y recomendaciones de los artículos serán responsabilidad de los autores y no implica, necesariamente, a menos que así se indique, una posición oficial de la Revista, de la Escuela de Medicina o de la Universidad de Costa Rica.

\section{Frecuencia de publicaciones}

La Revista publicará dos ediciones por año, es decir, tiene carácter semestral, mismo que podría ampliarse si la calidad y cantidad de las publicaciones lo ameritase.

La revista no aceptará anuncios comerciales de ningún tipo.

\section{Licencias de la Revista}

La Revista utiliza las licencias de Creatives Commons (CC) para proteger sus derechos de autor y para garantizar el acceso libre y abierto, específicamente la CC-BY-NC. 